\title{
PERILAKU KELUARGA SADAR GIZI DENGAN STATUS GIZI ANAK BADUTA DI KABUPATEN MAMUJU
}

\author{
Andi Salim, Muh. Hasyim \\ Jurusan Gizi Poltekkes Kemenkes Mamuju
}

\begin{abstract}
Malnutrition problems in Mamuju is still high in 2014. The results of nutritional assement status (PSG) in West Sulawesi on 2014 is underweight 39.7\%, very underweight 20.5\% and stunting $39.9 \%$ from the highest of five districts. The aim of this study is to determine the relationship between the incidence of behavior Kadarzi with undeweight and stunting. Samples of this study are children aged $0-24$ months with total population with 150 children. Independent variable is Kadarzi behavior of the family, dependent variabel is nutritional status and sub variable is age, gender, body weight and body lenght. Samples were obtained through interviews and direct measurements from children. The method is analitic survey with cross sectional study. Statistical test with T test (Independent T-Test). The result is there was a relation between behavior of kadarzi with underweight and thin, there is no relation between behavior of kadarzi and stunting.
\end{abstract}

\section{Keyword: kadarzi, nutrition status, child}

\section{PENDAHULUAN}

Salah satu upaya global dari berbagai negara dalam rangka memperkuat komitmen dan rencana aksi percepatan perbaikan gizi adalah SUN (Scaling Up Nutrition) Movement, khususnya penanganan gizi sejak 1.000 hari dari masa kehamilan hingga anak usia 2 tahun. Gerakan ini merupakan respon negara-negara di dunia terhadap kondisi status gizi di sebagian besar negara berkembang dan akibat kemajuan yang tidak merata dalam mencapai tujuan pembangunan milenium/MDGs (Goal 1). Gerakan 1000 HPK terdiri dari intervensi gizi spesifik dan intervensi gizi sensitive. Intervensi spesifik, adalah kegiatan yang umumnya dilakukan oleh sektor kesehatan, seperti imunisasi, PMT ibu hamil dan balita, monitoring pertumbuhan balita di Posyandu, suplemen tablet besi-folat ibu hamil, promosi ASI Eksklusif, MP-ASI dan sebagainya (Departemen Kesehatan RI, 2009).

Status gizi balita di Indonesia masih memperihatinkan. Hasil Riskesdas tahun 2010 terjadi penurunan prevalensi balita pendek dari $36,8 \%$ tahun 2007 menjadi $35,6 \%$ pada tahun 2010 (Roesli, 2000), namun pada tahun 2013 meningkat menjadi $37,2 \%$, anak stanting di Sulawesi Barat sebesar 48,0\% (Kementerian Kesehatan RI, 2014). Hasil survey PSG 2014 dilaporkan Balita kategori pendek dan sangat pendek sebanyak 39,4\%. Kabupaten Mamuju, anak stanting $(47,3 \%)$ (Kementerian Kesehatan RI, 2014), (39,9\%) (Dinas Kesehatan Propinsi Sulawesi Barat, 2015).
Perilaku sadar gizi masyarakat di Mamuju sangat rendah, hasil Riskesdas 2013 menggambarkan cakupan masih di bawah ratarata Nasional. Cakupan pemberian Vitamin A $75,7 \%$, penimbangan balita 6 bulan terakhir $\geq 4$ kali 57,0\%, konsumsi Fe Ibu Hamil 33,3\%, Sulawesi Barat, pemberian Vit. A $59.4 \%$, penimbangan Balita $\geq 4$ kali 6 bln terakhir $46.3 \%$, Fe ibu hamil 18,4\%, ASI esklusif $72.5 \%$, penggunaan garam yodium 72,5 (Kementerian Kesehatan RI, 2014), (61,9\%) (Dinas Kesehatan Propinsi Sulawesi Barat, 2015) Kabupaten Mamuju, penimbangan balita teratur $\geq 4$ kali dalam 6 bln terakhir $29.7 \mathrm{Fe}$ ibu hamil 16,0\%, Garam yodium 78,7\%, Vitamin A $57,0 \%$ (Kementerian Kesehatan RI, 2014) ASI esklusif 73,0\% (Dinas Kesehatan Propinsi Sulawesi Barat, 2015).

Tujuan penelitian ini dilakukan untuk memperoleh gambaran adanya hubungan antara perilaku sadar gizi keluarga (makan aneka ragam makanan, ASI Esklusif, penimbangan balita, pemberian suplemen dan penggunaan garam beryodium di rumah tangga) dengan status gizi pada Balita (indeks BB/TB) di Desa Tadui, Kabupaten Mamuju. Masalah penelitian dirumuskan dalam bentuk pertanyaan penelitain yaitu "apakah ada hubungan antara perilaku sadar gizi keluarga dengan terjadinya masalah gizi pada Balita. Hasil yang diperoleh diharapkan dapat dijadikan sebagai salah satu alternatif untuk mengatasi masalah gizi di wilayah ini. 


\section{METODE}

\section{Jenis Penelitian}

Jenis penelitian adalah Survey Analitik dengan pendekatan cross sectional study.

\section{Lokasi dan Waktu Penelitian}

Penelitian dilaksanakan di Desa Tadui Kecamatan Mamuju Kabupaten Mamuju Sulawesi Barat pada bulan Agustus sampai dengan Nopember Tahun 2015.

\section{Populasi dan Sampel}

Populasi dalam penelitian ini adalah semua keluarga yang memiliki anak badua di usia 0 24 bulan. Sampel adalah seluruh populasi atau metode sampling yang digunakan adalah total sampling.

\section{Teknik Pengumpulan Data}

Variabel independen adalah perilaku sadar gizi, dengan sub variabel antara lain kebiasaan makan aneka ragam, penimbanan balita secara teratur, pemberian ASI esklusif, pemberian suplemen, dan pengunaan garam beryodium. Variabel dependen adalah status gizi balita, dengan sub variabel adalah umur, jenis kelamin, BB dan PB baduta. Variabel independen diukur berdasarkan standar kadarzi, dan status gizi diukur secara antropomerti (antro WHO 2007), mengggunakan indeks $\mathrm{BB} / \mathrm{TB}$; gizi buruk (<-3SD), gizi kurang $(-3 \mathrm{~s} / \mathrm{d}$ $<-2 \mathrm{SD})$, gizi normal (-2 s/d $2 \mathrm{SD})$ dan gizi lebih (> 2 SD).

\section{HASIL PENELITIAN}

Karakteristik Sampel

Karakteristik adalah variabel yang melekat pada setiap populasi dan memiliki persamaan atau perbedaan dengan yang lain. Karakteristik anak baduta berdasarkan kelompok umur dan jenis kelamin sebagaimana digambarkan pada tabel 1. berikut ini:

Tabel 1. Distribusi Karakteristik Anak Baduta berdasarkan Umur dan Jenis Kelamin di Desa Tadui Kabupaten Mamuju

\begin{tabular}{ccccc}
\hline \multirow{2}{*}{$\begin{array}{c}\text { Kelompok } \\
\text { Umur }(\text { Bulan) }\end{array}$} & \multicolumn{2}{c}{ Jenis Kelamin $(\mathbf{n = 1 5 0})$} & \multicolumn{2}{c}{ Jumlah } \\
\cline { 2 - 5 } & Laki-Laki & Wanita & n & \% \\
\hline $0-5$ & 16 & 19 & 35 & 23,3 \\
$6-11$ & 16 & 16 & 32 & 21,3 \\
$12-24$ & 56 & 27 & 83 & 55,4 \\
Total & 88 & 62 & 150 & 100,0 \\
\hline
\end{tabular}

Dalam penelitian ini, sampel paling banyak adalah kelompok umur 12 - 24 bulan, dari jumlah tersebut sampel dengan jenis kelamin laki-laki sebanyak 37,33\%.

Tabel 2. Distribusi Masalah Gizi pada Baduta (0 - 24 Bulan) berdasarkan Kelompok Umur di Desa Tadui Kabupaten Mamuju

\begin{tabular}{ccccccc}
\hline \multirow{2}{*}{$\begin{array}{c}\text { Kelompok } \\
\text { Umur (Bulan) }\end{array}$} & $\begin{array}{c}\text { Gizi } \\
\text { Buruk }\end{array}$ & $\begin{array}{c}\text { Gizi } \\
\text { Kurang }\end{array}$ & $\begin{array}{c}\text { Gemuk- } \\
\text { Pendek }\end{array}$ & $\begin{array}{c}\text { Kurus - } \\
\text { Pendek }\end{array}$ & n & $\%$ \\
\hline $0-5$ & 0 & 0 & 1 & 0 & 1 & 8,3 \\
$6-11$ & 0 & 0 & 1 & 0 & 1 & 8,3 \\
$12-24$ & 1 & 2 & 0 & 7 & 10 & 83,3 \\
Total & 1 & 2 & 2 & 7 & 12 & 100,0 \\
\hline
\end{tabular}

Masalah gizi ditentukan berdasarkan 3 indikator; gizi buruk $(\mathrm{BB} / \mathrm{U}, \mathrm{TB} / \mathrm{U}, \mathrm{BB} / \mathrm{TB}<-3$ $\mathrm{SD})$, gizi kurang $(-3 \mathrm{~s} / \mathrm{d}<-2 \mathrm{SD})$, gemuk pendek $(\mathrm{BB} / \mathrm{TB}>2 \mathrm{SD}$ dan $\mathrm{TB} / \mathrm{U}<-2 \mathrm{SD})$, kurus pendek $(\mathrm{BB} / \mathrm{TB}<-2 \mathrm{SD}$ dan $\mathrm{TB} / \mathrm{U},-2$ SD. Masalah gizi pada Baduta pada penelitian 
ini lebih banyak pada kelompok umur $12-24$ bulan yaitu sebanyak 10 orang $(83,3 \%)$.

Tabel 3. Distribusi Perilaku Kadarzi menurut Kelompok Umur Baduta di Desa Tadui Kabupaten Mamuju

\begin{tabular}{cccccc}
\hline Perilaku & \multicolumn{3}{c}{ Kelompok Umur $(\mathbf{n = 1 5 0})$} & \multicolumn{2}{c}{ Jumlah } \\
\cline { 2 - 6 } Kadarzi & $\mathbf{0 - 5}$ Bulan & $\mathbf{6 - 1 1}$ Bulan & $\mathbf{1 2}-\mathbf{2 4}$ Bulan & n & \% \\
\hline Ya & 17 & 13 & 26 & 56 & 37,3 \\
Tidak & 18 & 19 & 57 & 94 & 62,7 \\
Total & 35 & 32 & 83 & 150 & 100 \\
\hline
\end{tabular}

Hasil penelitian diperoleh bahwa di Desa Tadui sebahagian besar keluarga $(62,7 \%)$ belum berperilaku sadar gizi, dan lebih banyak pada kelompok umur $(12-24)$.

Tabel 4. Hubungan Perilaku Kadarzi dengan Status Gizi Baduta (0 - 24 Bulan) dengan Indeks TB/U di Desa Tadui Kabupaten Mamuju

\begin{tabular}{cccccccc}
\hline \multirow{2}{*}{$\begin{array}{c}\text { Perilaku } \\
\text { Kadarzi }\end{array}$} & \multicolumn{2}{c}{ Status Gizi dengan Indeks TB/U (n=150) } & \multicolumn{2}{c}{ Jumlah } & \multirow{2}{*}{$\boldsymbol{\rho}^{\mathbf{a}}$} \\
\cline { 2 - 6 } & Sangat Pendek & Pendek & Normal & Tinggi & n & $\%$ & \\
\hline Ya & 6 & 8 & 38 & 4 & 56 & 37,3 & \multirow{2}{*}{0,760} \\
Tidak & 10 & 19 & 60 & 5 & 94 & 62,7 & \\
\hline a: Chy Square & & & & & & &
\end{tabular}

Tabel 5. Hubungan Perilaku Kadarzi dengan Status Gizi Baduta (0 - 24 Bulan) dengan Indeks BB/U di Desa Tadui Kabupaten Mamuju

\begin{tabular}{ccccccccc}
\hline \multirow{2}{*}{$\begin{array}{c}\text { Perilaku } \\
\text { Kadarzi }\end{array}$} & \multicolumn{3}{c}{ Status Gizi dengan Indeks BB/U (n=150) } & \multicolumn{3}{c}{ Jumlah } & \multirow{2}{*}{$\boldsymbol{\rho}^{\mathbf{a}}$} \\
\cline { 2 - 8 } & BB Sangat Kurang & BB Kurang & BB Normal & BB Lebih & $\mathbf{n}$ & $\boldsymbol{\%}$ & \\
\hline Ya & 4 & 8 & 43 & 1 & 56 & 37,3 & \multirow{2}{*}{0,128} \\
Tidak & 7 & 28 & 58 & 1 & 94 & 62,7 & \\
\hline a. Chy Square & & & & & & &
\end{tabular}

${ }^{\mathrm{a}}$ : Chy Square

Tabel 6. Hubungan Perilaku Kadarzi dengan Status Gizi Baduta (0 - 24 Bulan) dengan Indeks BB/TB di Desa Tadui Kabupaten Mamuju

\begin{tabular}{ccccccccc}
\hline \multirow{2}{*}{$\begin{array}{c}\text { Perilaku } \\
\text { Kadarzi }\end{array}$} & \multicolumn{4}{c}{ Status Gizi dengan Indeks BB/TB (n=150) } & \multicolumn{2}{c}{ Jumlah } & \multirow{2}{*}{$\boldsymbol{\rho}^{\mathbf{a}}$} \\
\cline { 2 - 7 } & Sangat Kurus & Kurus & Normal & Gemuk & $\mathbf{n}$ & $\boldsymbol{\%}$ & \\
\hline Ya & 2 & 11 & 38 & 5 & 56 & 37,3 & \multirow{2}{*}{0,851} \\
Tidak & 11 & 11 & 72 & 0 & 94 & 62,7 & \\
\hline${ }^{a}:$ Chy Square & & & & & & &
\end{tabular}

Ada beberapa indikator yang digunakan untuk menentukan status gizi balita. TB/U digunakan untuk mengetahui status gizi anak pada masa lalu. Anak yang mengalami masalah gizi pada waktu lampau pertumbuhannya akan terhambat sehingga kelihatan pendek dari teman seusianya.
Pada penelitian ini, anak sangat pendek dan pendek lebih banyak ditemukan pada keluarga yang tidak Kadarzi yaitu 29 (30,8\%) anak, anak dengan BB kurang dan sangat kurang sebanyak $35(37,2 \%)$ orang juga terdapat pada keluarga tidak sadar gizi. Demikian pula dengan anak yang kurus dan 
sangat kurus 22 (23,4\%). Berdasarkan uji statistik diperoleh bahwa status gizi baduta berdasarkan indeks $\mathrm{BB} / \mathrm{TB}$ dan $\mathrm{BB} / \mathrm{U}$ maupun indeks $\mathrm{TB} / \mathrm{U}$ diperoleh hasil nilai $\mathrm{p}>0,05$, artinya tidak ada hubungan antara keluarga sadar gizi dengan status gizi baduta.

\section{PEMBAHASAN}

Hubungan Perilaku Kadarzi dengan Status Gizi berdasarkan indeks BB/U

Status gizi berdasarkan indeks $\mathrm{BB} / \mathrm{U}$ adalah penggambaran dari keadaan anak saat ini, dan indikator ini sangat dipengeruhi oleh konsumsi anak saat ini karena BB dangat sensitif teerhadap perubahan lingkungan sekitar. Dilihat dari keragaman susunan hidangan makanan, pola makanan yang memenuhi gizi seimbang jika mengandung unsur zat tenaga yaitu makanan pokok, zat pembangun dan pemelihara jaringan yaitu laukpauk, dan zat pengatur yaitu sayur dan atau buah (Nadimin, 2010). Asupan makanan yang kurang beragam secara terus menerus dalam waktu yang lama berisiko mengalami kekurangan gizi atau gizi kurang. Hasil penelitian sejenis yang sebelumnya telah dilakukan (Nadimin, 2010) pada Balita umur 12 - 59 bulan, diperoleh bahwa sebagian besar (75\%) mereka mengkonsumsi hidangan dengan komposisi yang tidak memenuhi gizi seimbang, ditemukan adanya hubungan antara kejadian balita kurang gizi dengan asupan aneka ragam makanan anak. BB sangat erat kaitannya dengan asupan makanan. Pada penelitian ini diperoleh bahwa terdapat hubungan yhang signifikan antara perilaku kadarzi keluarga dengan status gizi berdasarkan indeks $\mathrm{BB} / \mathrm{U}$, hasil uji statistik diperoleh nilai $\mathrm{p}>0,05$.

\section{Hubungan Perilaku Kadarzi dengan Status Gizi berdasarkan indeks TB/U}

Tinggi badan anak menggambarkan keadaannya pada beberapa waktu yang telah lampau, karena TB tidak sensitif terhadap perubahan, maka perubahan TB yang diukur saat ini dapat dilihat setelah beberapa bulan kedepan. Asupan gizi anak pada masa lampau sangat erat kaitannya dengan pemberian ASI dan MP-ASI. Dimana ASI merupakan makanan terbaik bagi anak sampai anak berumur 24 bulan (Departemen Kesehatan RI, 2009). Berbagai penelitian telah membuktikan bahwa ASI mempunyai peran sangat besar terhadap perbaikan status gizi anak usia $0-24$ bulan. Penelitian terhadap anak umur $6-59$ bulan, dimana dilaporkan bahwa terdapat hubungan yang signifikan antara pemberian ASI ekslusif dengan status gizi balita (Nadimin, 2010).

Pada penelitian ini diperoleh bahwa hasil uji statistik diperoleh nilai $\mathrm{p}>0.05$, artinya tidak ada hubungan yang signifikan antara pertambahan TB anak dengan perilaku Kadarzi keluarga. Adanya perbedaan antara teori maupun penelitian yang telah dilakukan sebelumnya, salah satu yang kemungkinan menjadi penyebab adalah pada penelitian ini cakupan ASI esklusif dan vitamin A masih rendah.

\section{Hubungan Perilaku Kadarzi dengan Status Gizi berdasarkan indeks BB/TB}

Status gizi berdasarkan indeks BB/TB, menggambarkan keadaan anak baik masa lampau maupun saat ini. Seorang anak bisa bisa status gizi normal jika seimbang antara BB dan TBnya, kedua variabel tersebut tidak sesuai dengan umurnya. Vitamin A, disamping berperan dalam proses penglihatan, vitamin A diperlukan untuk pertumbuhan dan meningkatkan kekebalan tubuh anak. Pada balita, defisiensi vitamin A mengakibatkan terjadinya hambatan pertumbuhan sebagai akibat terhambatnya sintesa protein, vitamin A dibutuhkan untuk perkembangan tulang dan sel epitel yang membentuk email gigi. Pada orang yang kekurangan vitamin $\mathrm{A}$, pertumbuhan tulang terhambat dan bentuk tulang tidak normal. Pada anak-anak yang kekurangan vitamin A terjadi kegagalan pertumbuhan (Astawan, 2010). Vitamin A berpengaruh terhadap fungsi kekebalan tubuh manusia dan hewan. Sistem kekebalan membantu mencegah atau melawan infeksi dengan cara membuat sel darah putih yang dapat menghancurkan berbagai bakteri dan virus berbahaya. Retinol berpengaruh terhadap pertumbuhan dan diferensiasi limfosit B, yaitu leukosit yang berperan dalam proses kekebalan humoral. Hasil penelitian yang sebelumnya telah dilakukan terhadap anak umur $6-59$ bulan dilaporkan bahwa terdapat hubungan yang signifikan antara status gizi dengan pemberian vitamin A pada balita (Nadimin, 2010). Pada penelitian ini didapatkan hasil uji statistik nilai $\mathrm{P}>0.05$ artinya tidak terdapat hubungan signifikan antara perilaku Kadarzi dengan staus gizi berdasarkan indeks BB/TB. 


\section{KESIMPULAN}

Kejadian anak baduta dengan BB kurang maupun sangat kurang tidak berhubungan dengan perilaku sadar gizi keluarganya (Kadarzi), kejadian anak pendek maupun sangat pendek tidak ada kaitannya dengan perilaku sadar gizi keluarga saat ini, anak kurus maupun sangat kurus pada baduta erat kaitannya dengan perilaku keluarga baik saat ini maupun pada waktu yang lampau.

\section{DAFTAR PUSTAKA}

Arisman. (2009). Gizi dalam Daur Kehidupan. Jakarta: EGC.

Astawan, M. (2010, Januari - Juni). Vitamin A Bukan Hanya untuk Mata. Media Gizi Pangan, IX(1). Retrieved November 1, 2015.

Departemen Kesehatan RI. (2002). Pedoman Pelaksanaan Garam Beryodium di Tingkat Masyarakat. Jakarta.

Departemen Kesehatan RI. (2009). Pedoman Umum Gizi Seimbang, Panduan untuk Petugas. Jakarta.

Dinas Kesehatan Propinsi Sulawesi Barat. (2015). Pemantauan Status Gizi Tahun 2014. Mamuju.

Kementerian Kesehatan RI. (2011). Keputusan Menteri Kesehatan Republik Indonesia nomor: 1995/menkes/sk/xii/2010 tentang standar Antropometri Penilaian Status Gizi Anak. Jakarta: Direktorat Bina Gizi dan Kesehatan Ibu dan Anak, Direktorat Bina Gizi.

Kementerian Kesehatan RI. (2011). Riset Kesehatan Dasar Tahun 2010. Jakarta.

Kementerian Kesehatan RI. (2014). Riset Kesehatan Dasar Tahun 2014. Jakarta.

Kementerian Kesejahteraan Rakyat. (2013). Pedoman Perencanaan Program Gerakan Nasional Percepatan Perbaikan Gizi.

Muchtadi, D. (2009). Pengantar Ilmu Gizi. Bandung: Alfabeta.
Nadimin. (2010, Juli - Desember). Hubungan Kadarzi dengan Status Gizi Balita Umur 6 - 59 Bulan. Media Gizi Pangan, X (2), 2 - 4. Retrieved November 20, 2015.

Arisman. (2009). Gizi dalam Daur Kehidupan. Jakarta: EGC.

Astawan, M. (2010, Januari - Juni). Vitamin A Bukan Hanya untuk Mata. Media Gizi Pangan, IX(1). Retrieved November 1, 2015.

Departemen Kesehatan RI. (2002). Pedoman Pelaksanaan Garam Beryodium di Tingkat Masyarakat. Jakarta.

Departemen Kesehatan RI. (2009). Pedoman Umum Gizi Seimbang, Panduan untuk Petugas. Jakarta.

Dinas Kesehatan Propinsi Sulawesi Barat. (2015). Pemantauan Status Gizi Tahun 2014. Mamuju.

Kementerian Kesehatan RI. (2011). Keputusan Menteri Kesehatan Republik Indonesia nomor: 1995/menkes/sk/xii/2010 tentang standar Antropometri Penilaian Status Gizi Anak. Jakarta: Direktorat Bina Gizi dan Kesehatan Ibu dan Anak, Direktorat Bina Gizi.

Kementerian Kesehatan RI. (2011). Riset Kesehatan Dasar Tahun 2010. Jakarta.

Kementerian Kesehatan RI. (2014). Riset Kesehatan Dasar Tahun 2014. Jakarta.

Kementerian Kesejahteraan Rakyat. (2013). Pedoman Perencanaan Program Gerakan Nasional Percepatan Perbaikan Gizi.

Muchtadi, D. (2009). Pengantar Ilmu Gizi. Bandung: Alfabeta.

Nadimin. (2010, Juli - Desember). Hubungan Kadarzi dengan Status Gizi Balita Umur 6 - 59 Bulan. Media Gizi Pangan, X(2), 2 - 4. Retrieved November 20, 2015.

Roesli, U. (2000). Mengenal ASI Eksklusif. Jakarta: Niaga Swadayaran. 